\title{
1 Gophers as geomorphic agents in the Colorado Front Range
}

2 subalpine zone

4 Eric W. Winchell ${ }^{* a}$, Robert S. Anderson ${ }^{\mathrm{a}}$, Elizabeth M. Lombardi ${ }^{\mathrm{b}}$, Daniel F. Doak ${ }^{\mathrm{b}}$

5 a Department of Geological Sciences and Institute of Arctic and Alpine Research (INSTAAR),

6 University of Colorado, Boulder, Colorado 80309, USA

$7 \quad$ benvironmental Studies Program, University of Colorado, Boulder, Colorado 80309, USA

$8 \quad *$ corresponding author, Eric.Winchell@ colorado.edu

\section{Abstract}

10 Gophers are significant geomorphic agents in many landscapes. We document activity of the

11 Northern Pocket Gopher (Thomomys talpoides) in two small subalpine meadows (1050-1800 m²)

12 of the Front Range, Colorado, USA. We tracked locations and volumes of mounds and

13 subnivean infilled tunnels over one year and probed the thickness of the biomantle within one

14 meadow. We infer that only 5-7 gophers occupied each meadow, implying a gopher density of

$1528-67 \mathrm{ha}^{-1}$. Fractional areal coverage of the meadows by diggings suggests that within $49-95$

16 years gophers would fully resurface the meadows. Annual volumes of excavated soil correspond

17 to the equivalent of $\sim 1 \mathrm{~mm}$ of material spread evenly over the meadows. Probed meadow

18 resistance depths reveal a pattern we interpret to be stone lines at roughly $15 \mathrm{~cm}$ depths; implied

19 vertical turnover times are therefore roughly 150 years. These spatial and temporal patterns

20 imply that gophers should be able to churn the biomantle on approximately century timescales 
21 and should fully resurface the meadow areas in similar timescales. These field data also

22 contribute to an investigation of lateral sediment transport; given the local slope of the landscape,

23 gopher-driven sediment transport within our two study sites suggests a landscape diffusivity of

$240.008 \mathrm{~m}^{2} \mathrm{y}^{-1}$. At no time do gophers occupy the forest. As evidenced by subnivean infilled

25 tunnels, winter activity is restricted to the upslope (and hence upwind) meadow edges, which

26 correspond to high snow cover and warm $\left(>\sim 0^{\circ} \mathrm{C}\right)$ shallow subsurface soil temperatures.

27 Subsequent activity expands downhill into the meadows and shows a distinct pulse of mound

28 activity in late summer through early fall prior to snowfall. Local forest fire history has led to

29 much more extensive meadows in the past, suggesting that the geomorphic influence of gophers

30 in the landscape is much more widespread than the present distribution of meadows and may

31 cover the entire subalpine region of the Front Range on millennial timescales.

33 Keywords: biogeomorphology; gopher; hillslope; landscape evolution

\section{1. Introduction}

35 Biological agents and their effects are ubiquitous within landscapes and can be observed on daily

36 timescales. Deer-generated game trails, beaver-constructed dams, and ant-generated mounds are

37 several examples of the geomorphic impacts of animals that one can stumble across on many

38 landscapes. However, despite early interdisciplinary acknowledgement that biology plays a role

39 in landscape evolution (Darwin, 1881; Gilbert, 1909), geomorphologists and biologists have

40 largely worked independently. Even today, geomorphology largely ignores the role of the

41 biosphere or acknowledges it only in a broad, large-scale sense (Butler, 1995). This may be

42 because of fundamental differences between the two sciences when approaching problems. 
43 When presented with a question, instead of focusing on how animals and landscape evolution are

44 interwoven, Yoo et al. (2005) stated that an ecologist may concentrate on population dynamics

45 while a geomorphologist may concentrate on the energy that molds and drives the landscape.

46 Here we honor what is observed to be the primary geomorphic player within the subalpine

47 landscape of the Colorado Front Range, the Northern Pocket Gopher (Thomomys talpoides) and

48 provide a framework for understanding what drives the spatial and temporal patterns of

49 landscape change.

50 The Northern Pocket Gopher, Thomomys talpoides, is a medium-sized rodent: mean male total

51 length $=206.8 \mathrm{~mm}$, mean female total length $=203.0 \mathrm{~mm}$ (Miller, 1964); in Utah, mean adult

52 male mass $=104.4 \mathrm{~g}$, mean adult female mass $=91.4 \mathrm{~g}$ (Anderson, 1978). While slight on an

53 individual scale, they are often abundant and have a large geographic range that spans a large

54 fraction of western North America (Verts and Carraway, 1999). More broadly, pocket gophers

55 comprise multiple species within six genera widely distributed across North and Central 56 America. 


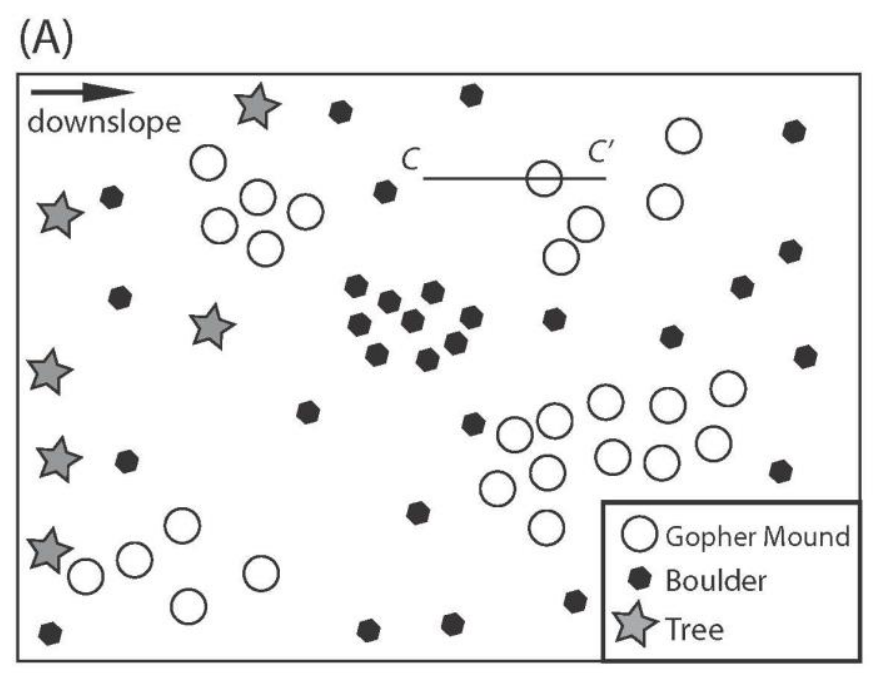

(B)

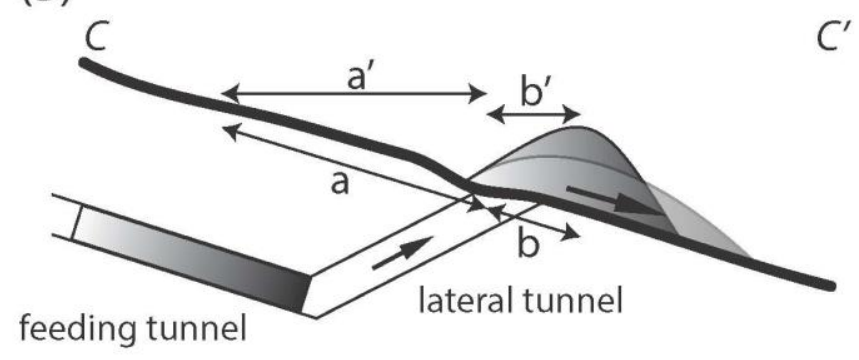

59 Fig. 1. (A) The general pattern of gopher activity in a boulder-strewn, sloping meadow-forest

60 landscape. Gophers inhabit the meadows but not the forests. Gopher mounds develop in a 61 patchy fashion within the meadows, presumably each patch belonging to a solitary gopher.

62 These patches generally occupy the less rocky portions of this glacial till mantled surface. (B)

63 Subsurface cross section (C-C') of gopher-driven sediment transport. Material is transported

64 from the ground-parallel feeding tunnel up through a lateral tunnel where it is deposited on the

65 surface as a mound. Material is then exposed to diffusive transport processes that move material

66 downslope. Gopher transport of sediment is described by Gabet (2000) as consisting of two

67 discrete horizontal distances: that from the centroid of the tunnel to the burrow exit/entrance $\left(a^{\prime}\right)$,

68 and that from the burrow exit/entrance to the centroid of the mound $\left(b^{\prime}\right)$; their surface-parallel

69 counterparts are $a$ and $b$. 
71 All pocket gophers are fossorial rodents that build an intricate system of tunnels and mounds

72 (Fig. 1). The subsurface gopher tunnel system can be separated into two parts: (i) shallow

73 feeding tunnels constructed parallel to the ground surface that are utilized for harvesting roots,

74 and (ii) a deeper set of tunnels and chambers that are utilized for nesting and food storage (e.g.,

75 Miller, 1957; Reichman and Seabloom, 2002). The feeding tunnels connect to the ground

76 surface through short tunnels, referred to as laterals (Fig. 1). Laterals are utilized to rid the

77 tunnel system of excavated material (Vleck, 1981). The first of the three primary gopher-

78 generated geomorphic features are found at the exit of these tunnels: surface mounds (Figs. 2 and $793 \mathrm{~A})$.

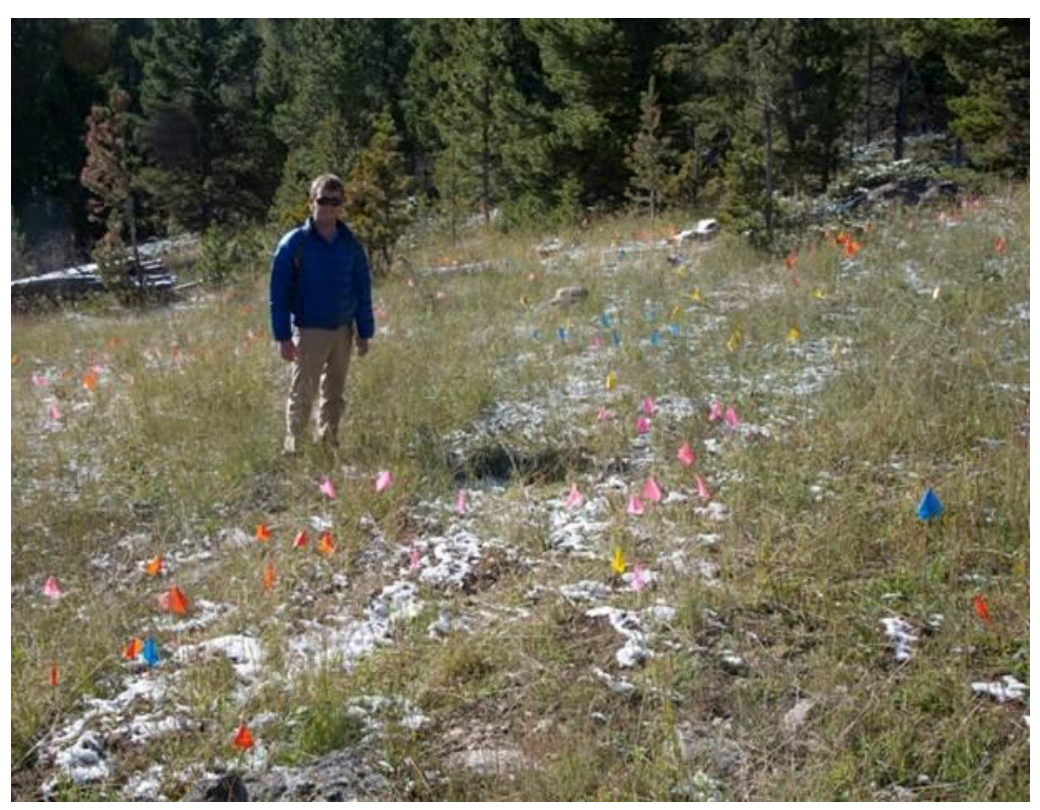

81 Fig. 2. Photograph illustrating one of two study sites where gopher mounds have been surveyed

82 throughout the snow-off season. Flags mark surveyed gopher mounds, each survey being 83 flagged by a different color of flag. Patchy thin snow in the meadow signifies the onset of 84 winter. 
86 The second is an infilled tunnel (Knight, 2009) (Fig. 3B) or earth cylinder (Warren, 1937).

87 These features are produced when a meadow is blanketed in snow, at which time gophers will

88 emerge from the soil to forage for plant material and, in doing so, create snow tunnels. Later,

89 they will further utilize these surface-level tunnels to rid the subsurface of their tillage (e.g.,

90 Grinnell, 1923). As a result, they generate dense soil cylinders that are revealed when the snow

91 retreats in early spring. The third geomorphic feature is a stone line (Fig. 3C).

92
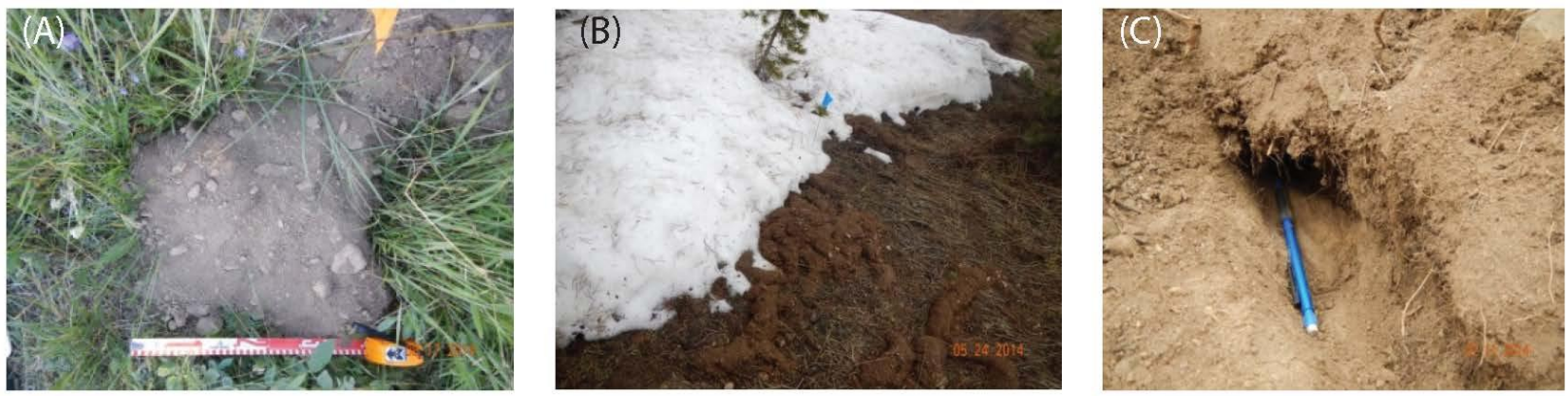

94 Fig. 3. Three primary geomorphic features generated by gophers. (A) A surface mound. Surface

95 area and average height of mounds are measured to acquire mound volume; geospatial position

96 was also documented. (B) Several infilled tunnels emerging from beneath melting snow cover.

97 Infilled tunnel volumes are calculated by assuming a cylindrical geometry and collecting length

98 and height measurements; we assumed a constant diameter in the horizontal dimension for all

99 infilled tunnels. Geospatial position was also documented. (C) A gopher tunnel with a stone on

100 the floor of the tunnel (beneath pencil). 
102 Stone lines are concentrations of stones at some depth beneath the ground surface and reflect a 103 threshold grain size, generally around $2.5 \mathrm{~cm}$ (Verts and Carraway, 1999), below which gophers 104 can excavate and above which gophers will dig around. As gopher tunneling continues, larger 105 grains will drop to a uniform depth that effectively records the maximum depth to which the 106 gophers are excavating. This depth, and the stones that accumulate at this depth, are referred to 107 as stone lines (Johnson, 1989). At the same time, the finer material will become more 108 concentrated above the stone line to produce what is called the biomantle, which includes the 109 surface mounds (Johnson, 1989).

110 For the pocket gopher, benefits of being fossorial (hidden from predators' vision, protection from 111 extreme weather events, and access to plant roots; Vleck, 1979) must outweigh the fact that 112 gophers utilize 360-3400 times the amount of energy tunneling than would be required to move 113 the same distance on the surface (Vleck, 1979). Furthermore, the pocket gopher is close to 114 indifferent to the drudgery of working against gravity. Seabloom et al. (2000) suggested that the 115 energetic costs associated with shearing and pushing soil horizontally through a tunnel system 116 are three orders of magnitude higher than the cost associated with lifting soil against gravity. 117 Gophers prefer to construct lateral tunnels on the downslope side of the connecting feeding 118 tunnel and at an angle that does not exceed the angle of repose (Seabloom et al., 2000); the angle 119 is a function of soil cohesion and is low enough to prevent lateral tunnels from collapsing inward 120 (Vleck, 1981).

121 The large energetic cost of excavation also suggests a premium for behaviors that maximize the 122 benefits of excavations, especially with regard to food acquisition and neighboring gophers 123 (Reichman et al., 1982). Substantial research has focused on how gophers strategize their tunnel 124 and burrow geometries. Pocket gophers minimize the cost of burrowing by choosing very 
125 specific segment lengths between the lateral tunnels (Vleck, 1981) while constructing, in some

126 cases, intricate tunnel systems over 100 m long (e.g., Criddle, 1930; Smallwood and Morrison,

127 1999). Importantly, the spacing between individual burrow systems remains fairly constant

128 regardless of vegetation type (Reichman et al., 1982). Gophers are less mobile once they have

129 found a hotspot for food resources. Reichman et al. (1982) suggest that burrow length and the

130 quantity of off-shooting tunnel branches are inversely proportional to the availability of food.

131 The geomorphic effect of the pocket gopher has also been investigated. Ellison (1946) discusses

132 the pocket gopher's role as an erosional agent within the Wasatch Plateau; while not the primary

133 cause of erosion in this landscape, it is still deemed a noteworthy erosional agent. Thorn (1978)

134 identified the pocket gopher as the dominant geomorphic agent in the alpine tundra of the Front

135 Range near our field site. Black and Montgomery (1991) studied gopher activity in a grassland

136 basin in northern California by documenting all gopher-generated surface mounds and concluded

137 that the burrowing of mammals is the primary process driving sediment transport in their field

138 area. Gabet et al. (2003) illustrated that at low gradients gopher bioturbation generates a greater

139 sediment flux than purely physical processes. Butler and Butler (2009) demonstrated that

140 gopher-generated mounds and infilled tunnels are less compacted than the surrounding

141 undisturbed soils and argued that these low density mounds and infilled tunnels may promote

142 seedling establishment within the alpine treeline. Gopher-driven microtopographic variation on

143 fertilized plots versus unfertilized plots was monitored by Inouye et al. (1997). Smallwood and

144 Morrison (1999) reported a variety of excavation statistics (including mean mound volume,

145 tunnel length, and burrow volume) for several pocket gopher species. Gabet (2000) documented

146 gopher-generated sediment transport near Santa Barbara, California, and explored its dependence

147 on slope angle. Cox and Allen (1987) discussed gopher-driven sediment transport as a process 
148 responsible for mima mounds; this has now been supported by numerical modeling (Gabet et al.,

149 2014). Finally, Zaitlin and Hayashi (2012) and references therein discussed how the pocket

150 gopher has the potential to drive geomorphic change on sloping landscapes. In this contribution,

151 we add to this list by documenting the temporal and spatial trends in gopher-driven surface

152 processes, the intensity of gopher activity, and associated geomorphic impacts within the

153 subalpine zone of the Colorado Front Range.

\section{2. Study area}

155 Our study area (Fig. 4) consists of two meadows in the subalpine of the Colorado Front Range 156 within the Boulder Creek Critical Zone Observatory (Anderson et al., 2012, 2013). This region 157 was glaciated during the Pleistocene (Madole et al., 1998); glacial till mantles both study sites.

158 Two meadow sites referred to as the 'upper site' (area $=1800 \mathrm{~m}^{2}$, elevation $\left.=3010 \mathrm{~m}\right)$ and

159 'lower site' $\left(\right.$ area $=1050 \mathrm{~m}^{2}$, elevation $=2975 \mathrm{~m}$ ) were established in the summer of 2013.

160 Meadows were selected based primarily upon (i) notable gopher activity, (ii) a sloping surface,

161 (iii) sharp forest-meadow boundaries, and (iv) being representative of the general geomorphic

162 setting (e.g., mantled with glacial till). The two sites are surrounded by forest composed

163 primarily of lodgepole pine and aspen, with lesser numbers of limber pine, Engelmann spruce,

164 and Douglas fir. Ungulates, including elk, mule deer, and moose (Armstrong et al., 2011), roam, 165 graze, and sleep in both study sites. 

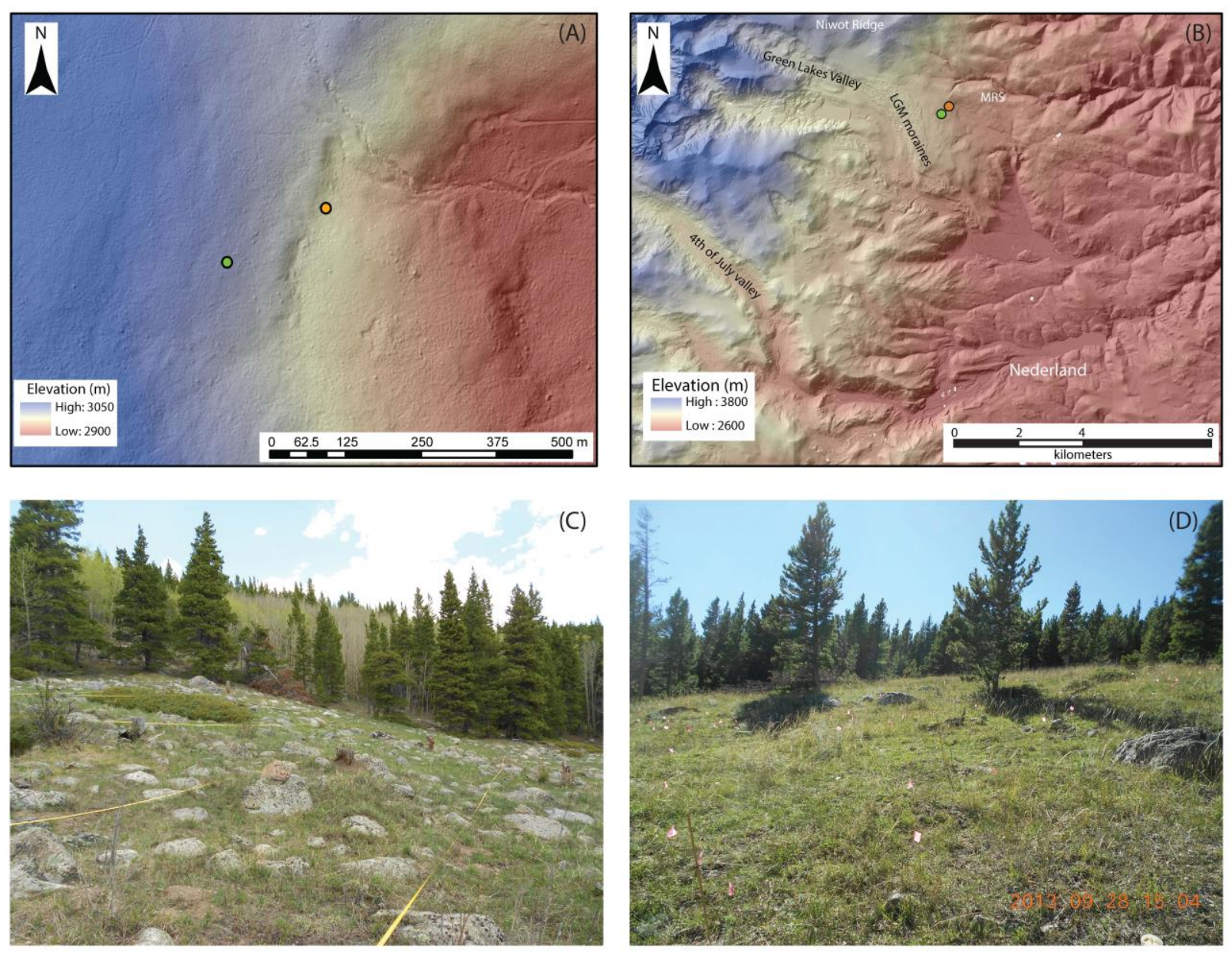

168 Fig. 4. Zoomed-in (A) and zoomed-out (B) views of LiDAR-derived digital elevation model

169 (DEM) provide the topographic context of the upper site (green dot) and the lower site (orange

170 dot) in the Front Range just west of Boulder, Colorado. Both sites were glaciated during the

171 Pleistocene as can be recognized by observing the glacially sculpted landscapes of nearby Green

172 Lakes and $4^{\text {th }}$ of July Valleys (B). Both sites are located immediately outboard of moraines

173 generated during the Last Glacial Maximum in an older moraine complex. Glacial till is

174 prevalent mantling both sites, as shown within the lower site (C) and upper site (D). 


\section{Methods}

176 Surface mounds were monitored on an approximately weekly basis once snow had largely

177 melted off the sites. Fresh mounds were identified by (i) being composed primarily of fines with

178 a lack of cobbles and gravels in the freshly excavated, visible mound surface coating; (ii) low

179 density of the mound material; and (iii) a lack of vegetation. The GPS coordinates of mound

180 locations were documented using a handheld Trimble GeoXT GNSS device equipped with Terra

181 Sync version 2.3. Reported maximum accuracy for these data are 0.3 to $1 \mathrm{~m}$ in open-canopy

182 conditions (average $0.3-0.5 \mathrm{~m}$ accuracy) and 0.5 to $>1.0 \mathrm{~m}$ in closed canopy conditions (average

$183>1.0 \mathrm{~m}$ accuracy) (Chamberlain, 2002; Trimble, 2005). Raw position data were differentially

184 corrected in Pathfinder Office version 5.40 (Trimble Navigation Limited, Sunnyvale, CA, USA)

185 against data collected and archived by UNAVCO (39 $59^{\prime} 43.994^{\prime \prime} \mathrm{N}, 105^{\circ} 15^{\prime} 44.2794{ }^{\prime}$ 'W,

186 elevation $1667 \mathrm{~m})$. The corrected coordinates were exported as shapefiles in Universal

187 Transverse Mercator 84 (UTM 84). By surveying on an approximately weekly basis,

188 misidentification of 'old' (generated prior to the 2014 digging cycle) versus 'new' mounds was

189 minimized as the metrics utilized to identify a mound as 'new' become less prominent over time.

190 Furthermore, the high frequency of our observations allowed us to document when an individual

191 mound was enlarged; we tabulated such an expansion as an independent 'mound-building event';

192 for the remainder of this paper we refer to each 'mound-building event' as simply a 'mound'. We

193 documented mound volumes by measuring the surface area of the base and the average height of

194 each mound. Mounds were marked with a pin flag, carefully placed to avoid invasion of the

195 connecting tunnel (Fig. 2). In cases where a mound expanded in volume between visits, full

196 mound volume was documented and the new mound material was calculated by subtraction of

197 the prior volume. 
198 Infilled tunnels were documented directly after snow retreated from the forest-meadow edges in 199 the spring of 2014. The infilled tunnel locations were documented using the same Trimble 200 system. Infilled tunnel volumes were calculated by assuming a cylindrical geometry and 201 collecting length and height measurements. The length of the infilled tunnel was measured by 202 mirroring the infilled tunnel surface with a rope and then measuring the length of the rope. To 203 calculate the cross-sectional area, we assumed a 7 -cm width for all infilled tunnels in the 204 horizontal dimension, measured the height of the infilled tunnel, and then averaged the two to 205 acquire an average radius. If infilled tunnel sections overlapped vertically, the overlapping 206 sections were considered to be a part of one and the same infilled tunnel.

207 All trees within the meadows and at the forest margins at the plot borders were identified to 208 species, mapped using the same Trimble system, and measured. Size was quantified by height 209 for trees under $2 \mathrm{~m}$ tall or diameter at breast height (DBH) if over $2 \mathrm{~m}$ tall.

210 The presence or absence of stone lines was documented by pounding $1.27-\mathrm{cm}$-diameter rebar 211 into the ground until substantial resistance was encountered. This was performed at the upper 212 site along multiple transects spanning the meadow region. Sampled lines were spaced $4 \mathrm{~m}$ apart, 213 each transect was between 60 and $70 \mathrm{~m}$ long and was sampled at 2-m increments. Three 214 measurements were surveyed at each location, avoiding surface glacial till. Meadow regions 215 were denoted as areas in which tree density was significantly lower than in the continuous forest. 216 We probed a total of 185 locations (555 total surveyed points) within the meadow. We surveyed 217 depth to resistance within the forest region as well, but the resistance encountered while 218 surveying within the forest could result from either stones or roots and thus the interpretation of 219 the resistance depths is ambiguous. We therefore omit further discussion of forest probe data. 220 On the other hand, as very few trees occur in the meadows and we find no roots in the one small 
221 pit we were allowed to dig in the meadow, we are confident that resistance in the meadow is very

222 largely from stones alone. To judge whether gophers are likely to have created the distribution

223 of depths we found, we also ran a simulation model 100 times to determine depths to resistance

224 in a randomized glacial till subsurface. In each model run we placed $\sim 190$ (model run

225 dependent) nonoverlapping clasts of a variety of sizes within a subsurface cross section that is 10

$226 \mathrm{~m}$ wide and $1.2 \mathrm{~m}$ deep. Cell width and height are $1 \mathrm{~cm}$. The radius for a clast is calculated by

227 evaluating the absolute value of the following: $5 \mathrm{~cm}$ plus $10 \mathrm{~cm}$ multiplied by a pseudorandom

228 value drawn from the standard normal distribution. For each of the 100 simulations, at each $\mathrm{cm}$

229 along the width of the cross section, the depth to the shallowest clast in the subsurface is

230 evaluated and recorded. If no clast exists at a given location, then the maximum depth of the

231 cross section $(120 \mathrm{~cm})$ is recorded. A probability distribution function (pdf) of the minimum

232 depth to clasts is generated at the end of each model run by dividing by the total number of

233 probed locations (1000).

234 We monitored subsurface temperatures with Thermochron iButtons between 11 July 2014 and 10

235 June 2015. The thermistors were inserted along a single transect at five locations spanning the

236 meadow-forest pair, roughly $20 \mathrm{~m}$ into the meadow, $5 \mathrm{~m}$ into the meadow, the forest-meadow

237 boundary, $5 \mathrm{~m}$ into the forest, and $20 \mathrm{~m}$ into the forest. At each location, one thermistor was

238 deployed at $2 \mathrm{~cm}$ depth and one at $10 \mathrm{~cm}$ depth; surface duff was excluded from the soil depth

239 measurements.

240 We monitored snow depth during the 2014-2015 winter at the forest-meadow edge at the upper

241 site with time-lapse photography. Each day, multiple still photos captured a view that includes a

242 vertical PVC pipe erected from the ground (supported by a deeply inserted rebar rod) and painted

243 at 10-cm intervals; snow depth was estimated based upon where the snow intersected the painted 
244 markings on the PVC pipe. A snow depth time series was generated from one photograph from

245 each winter day taken at either 10 or 11 a.m.

\section{4. Results}

\section{4.1. Excavation data}

248 We documented a total of 515 mounds and 66 infilled tunnels at the upper site, which has an area

249 of $1800 \mathrm{~m}^{2}$. Average mound height was $5 \mathrm{~cm}$, average mound surface area was $597 \mathrm{~cm}^{2}$, and 250 average mound volume was $4006 \mathrm{~cm}^{3}$. The average cross-sectional area of tunnel-fills was 27

$251 \mathrm{~cm}^{2}$ with average length of $122 \mathrm{~cm}$. Average tunnel-fill volume was $3849 \mathrm{~cm}^{3}$.

252 We surveyed a total of 131 mounds and 35 infilled tunnels at the lower site $\left(\right.$ area $=1050 \mathrm{~m}^{2}$ ). 253 Average mound height was $6 \mathrm{~cm}$, average mound surface area was $722 \mathrm{~cm}^{2}$, and average mound 254 volume was $5842 \mathrm{~cm}^{3}$. Average cross-sectional area of tunnel-fills was $25 \mathrm{~cm}^{2}$, and the average 255 length was $63 \mathrm{~cm}$. Average tunnel-fill volume was $1614 \mathrm{~cm}^{3}$.

256 In total, material volumes of $2.32 \mathrm{~m}^{3}$ and $0.82 \mathrm{~m}^{3}$ (Fig. 5) were brought to the surface in the form 257 of mounds and infilled tunnels at the upper and lower sites, respectively. Dividing by the area of 258 each meadow, this equates to an average of 1.3 and $0.8 \mathrm{~mm}$ of material being brought to the 259 surface over the upper and lower sites, respectively, within one annual digging cycle. Whereas 260 gopher activity was not uniform in either meadow, the calculation provides a general metric to 261 estimate the long-term geomorphic effect of gophers within the landscape.

262 Combined surface areas of mounds and infilled tunnels in the upper and lower sites are $36 \mathrm{~m}^{2}$ 263 and $11 \mathrm{~m}^{2}$, respectively. This is equivalent to $2 \%$ and $1 \%$ of the total area of the upper and lower 264 sites, respectively, and implies that the upper and lower sites will be resurfaced in time scales of 26549 and 95 years, respectively. 
266 The temporal pattern of mound formation at each site (Fig. 5) reveals three distinct patterns of 267 gopher activity: (i) tunnel-fills are constructed during the winter season and are

Upper Plot, Material Brought to Surface

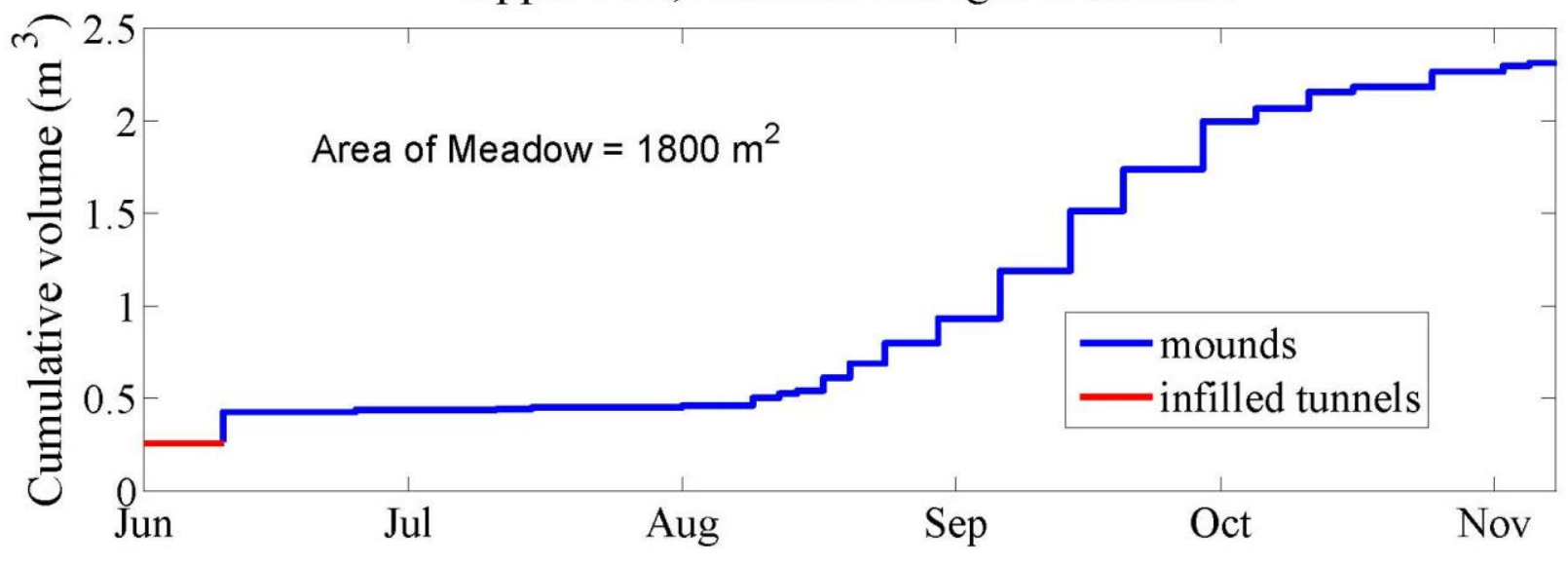

Lower Plot, Material Brought to Surface

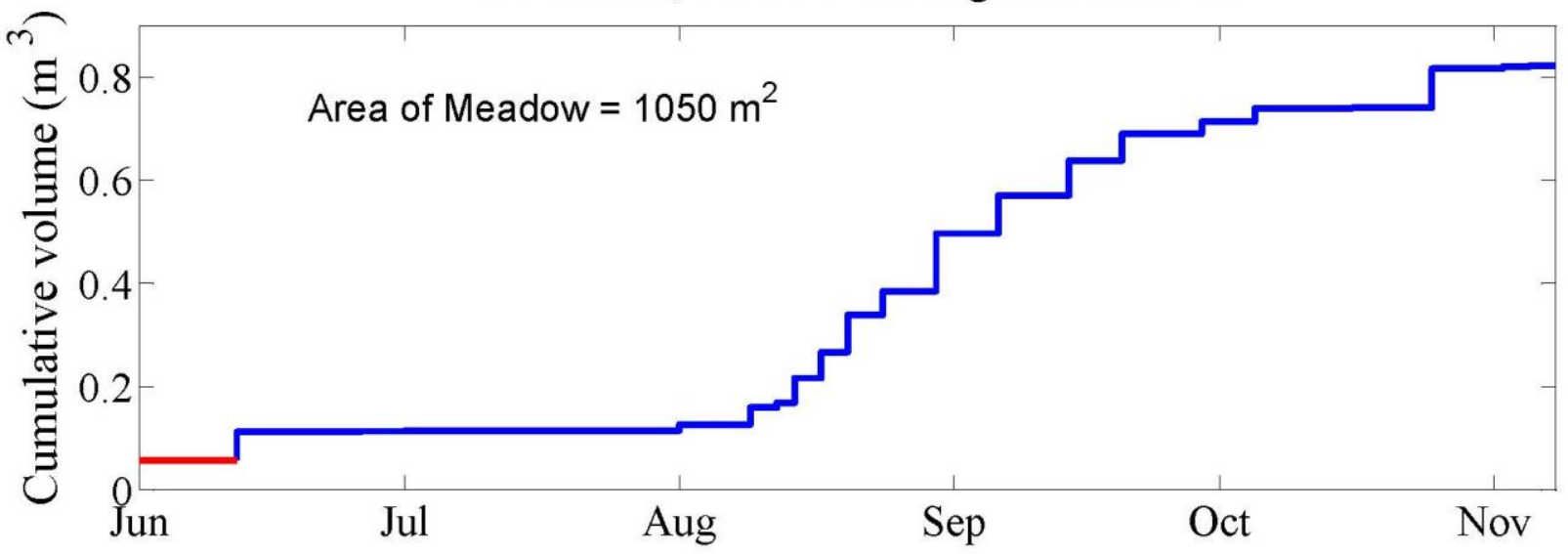

270 Fig. 5. Time series of surficial geomorphic work accomplished by gophers at each site (top panel

271 = upper site; bottom panel = lower site). Three distinct patterns of gopher activity appear: (i)

272 infilled tunnels (red) are constructed during the winter and are revealed when the snow retreats in

273 the spring/early summer, (ii) gopher mound generation was minor in mid-summer, until (iii) 
274 mound activity explodes at both sites in early-mid-August and then trails off in early-mid-

275 October before winter sets in in early November.

277 revealed when the snow retreats in the spring, (ii) gopher mound generation was rare during

278 early to mid-summer, until (iii) mound activity accelerated at both sites in early-mid-August and

279 then trails off in early-mid-October. Infilled tunnels are found only at the forest meadow edge.

280 Mounds emerge only in the meadow and in a 'patchy' fashion. We saw no gopher activity

281 within the forest (Fig. 6).

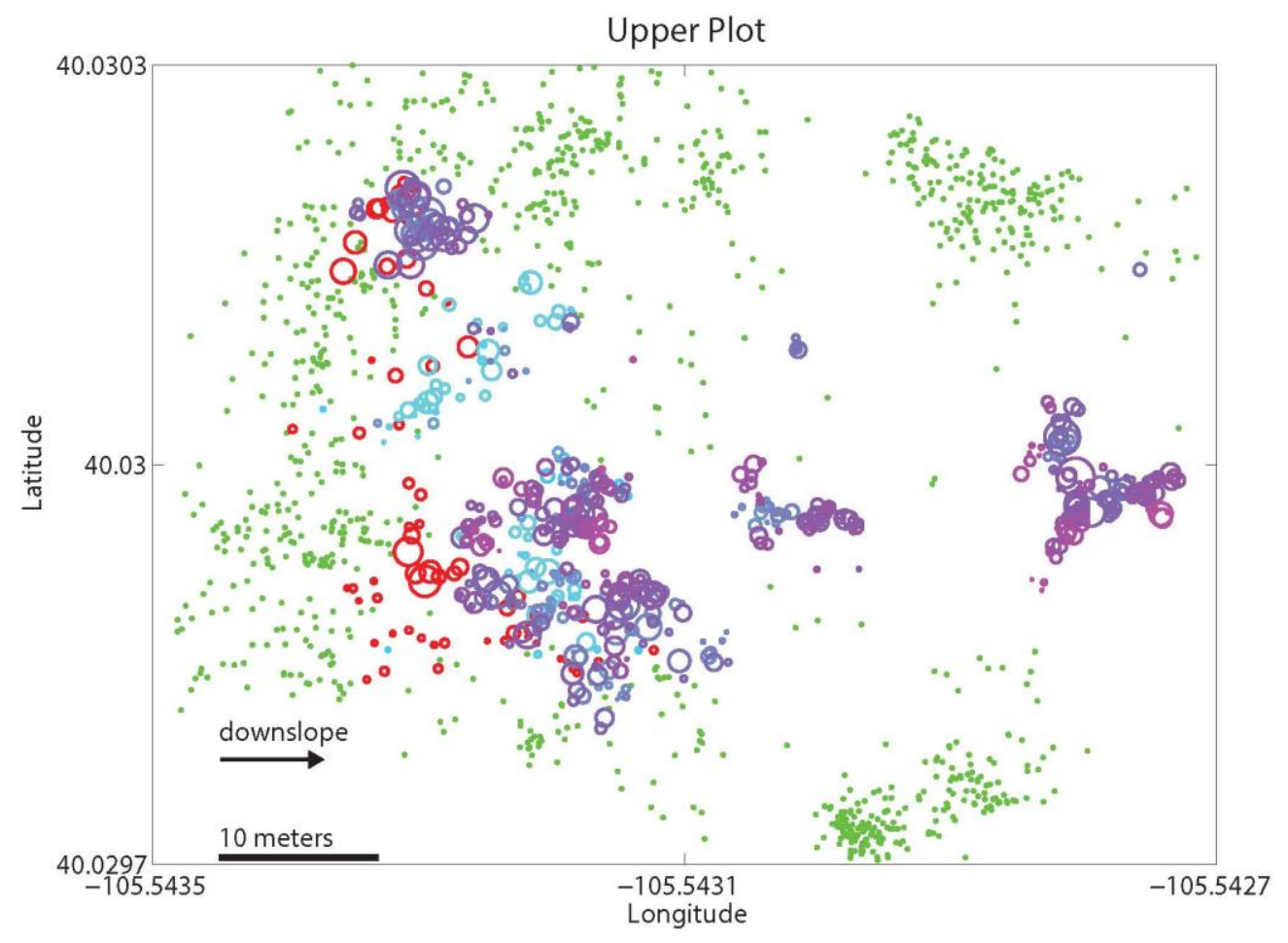

\begin{tabular}{|c|c|}
\hline - & Tree \\
\hline • & Infilled Tunnel \\
\hline - & $6 / 10$ \\
\hline - & $6 / 25$ \\
\hline - & $7 / 1$ \\
\hline - & $7 / 11$ \\
\hline - & $7 / 15$ \\
\hline - & $8 / 1$ \\
\hline - & $8 / 9$ \\
\hline - & $8 / 12$ \\
\hline - & $8 / 14$ \\
\hline - & $8 / 17$ \\
\hline - & $8 / 20$ \\
\hline - & $8 / 24$ \\
\hline - & $8 / 30$ \\
\hline - & $9 / 6$ \\
\hline - & $9 / 14$ \\
\hline - & $9 / 20$ \\
\hline - & $9 / 29$ \\
\hline - & $10 / 5$ \\
\hline - & $10 / 11$ \\
\hline - & $10 / 16$ \\
\hline - & $10 / 25$ \\
\hline - & $11 / 2$ \\
\hline • & $11 / 5$ \\
\hline - & $11 / 8$ \\
\hline
\end{tabular}

282 


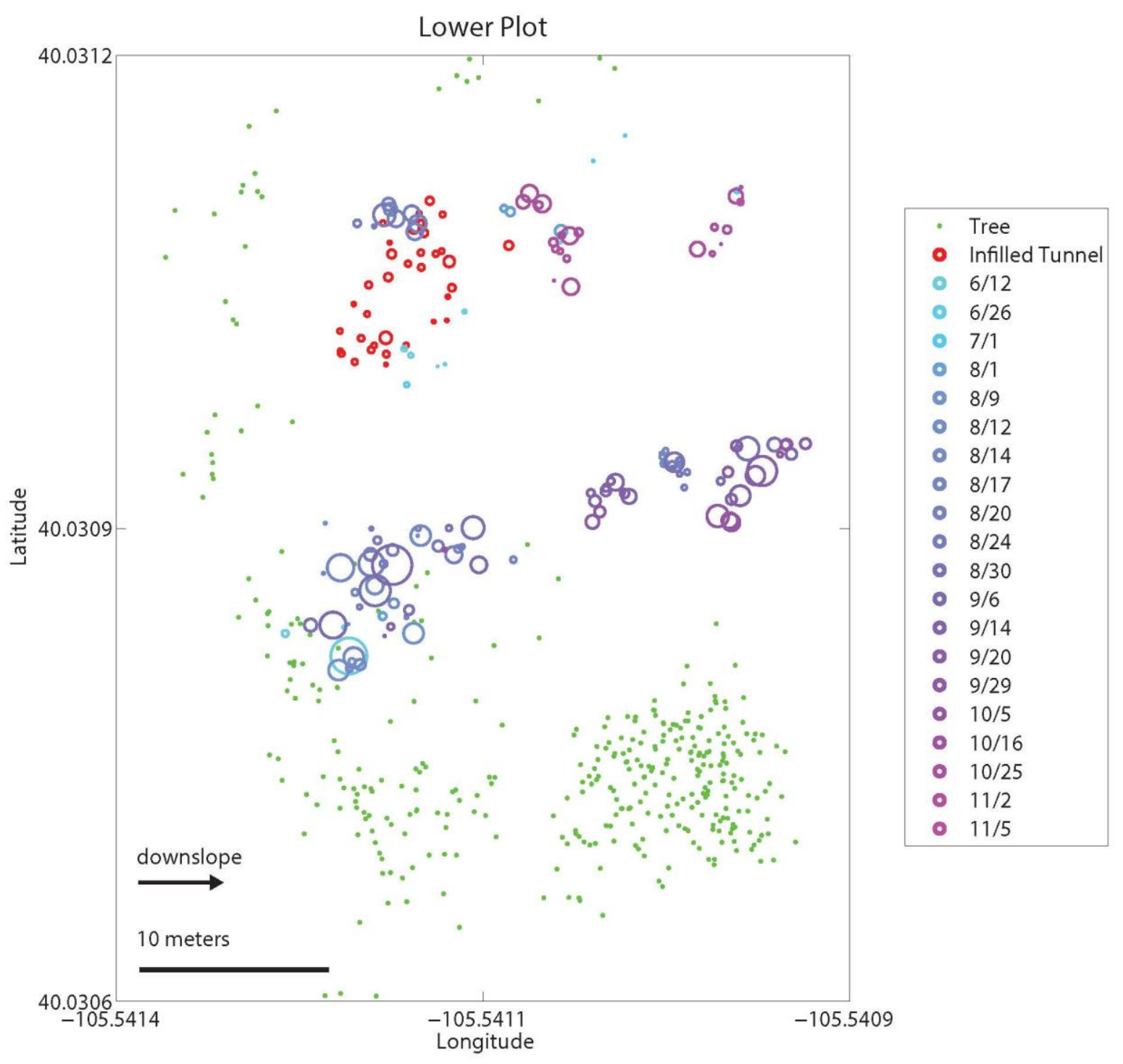

284 Fig. 6. Spatial relationship between mounds (blue/purple circles), infilled tunnels (red circles), 285 and trees (green dots) at the upper (top panel) and lower (bottom panel) sites. Landscape slopes 286 downhill to the right in both cases. Dominant wind is also west-to-east, so that the upslope edge 287 of the meadow is also the upwind edge. Infilled tunnel and mound circle sizes are scaled by 288 volume. Dates in the key denote the date when specific mounds were surveyed. To the extent 289 that infilled tunnels are proxies for gopher location in the winter, gophers appear to spend the 290 winter months primarily along the upslope, upwind forest-meadow edge. If mounds are proxies 
291 for gopher location during all other months, gophers spend these months primarily within the

292 meadow region. We hypothesize that this is driven by the spatial pattern of snow depth, which in

293 turn dictates the subsurface temperatures (see Fig. 8).

\section{4.2. Probing depths}

295 At the upper site, the depth to significant probe resistance in the meadow (Fig. 7A) reveals a 296 median resistance depth of $15 \mathrm{~cm}$ and a distribution that shows a distinct peak at $9-18 \mathrm{~cm}$ depth.

297 This contrasts with our modeled probability of encountering a clast, which declines 298 monotonically with depth in all simulations (Fig. 7B). The modeled and observed distributions

299 differ significantly, implying that some process has altered the subsurface since the glacial till 300 was deposited. We suggest that the primary process is the digging of gophers and that they have 301 generated stone lines akin to that documented by Johnson (1989).
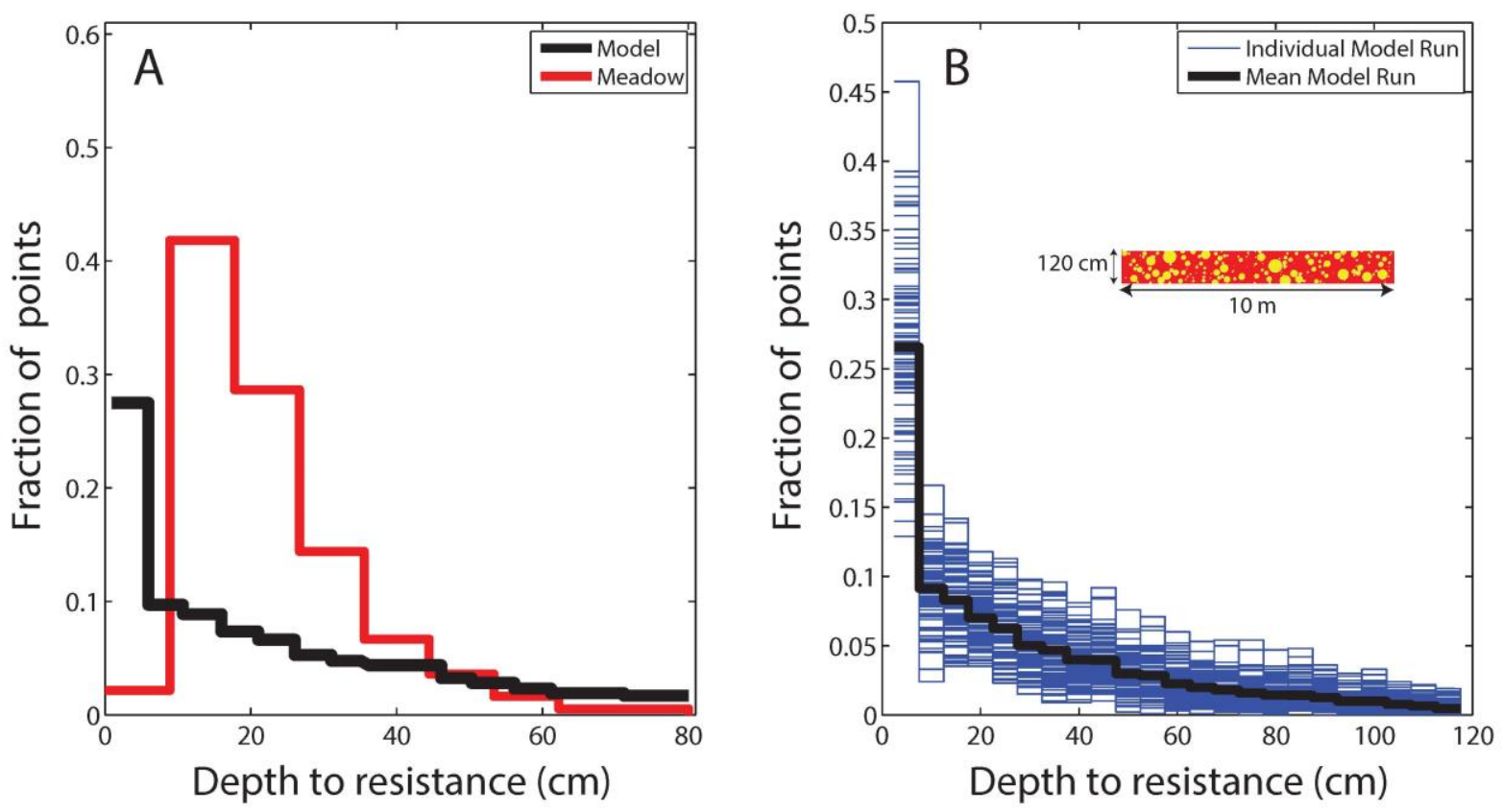

302 
303 Fig. 7. (A) Upper site meadow stone line survey data (red) juxtaposed with the mean of the

304 modeled stone line simulation (black) also shown in (B). The depth to significant probe

305 resistance within the meadow reveals a median resistance depth of $15 \mathrm{~cm}$. The distribution

306 displays a distinct maximum between the depths $9-18 \mathrm{~cm}$. This contrasts with the model, in

307 which the peak occurs in the top-most bin, $2.5-7.5 \mathrm{~cm}$. (B) All 100 model realizations of the

308 depth to resistance in randomized subsurfaces. One of the realizations of the randomized glacial

309 till subsurface is shown in the inset. All modeled distributions display a maximum in the top-

310 most bin and show no maximum at depth.

\section{4.3. Subsurface temperatures and snow depth}

312 At the forest-meadow boundary, snow was first present on 27 October 2014 and last appeared 23

313 May 2015. A maximum snow depth of $1.23 \mathrm{~m}$ was recorded on 26 February 2015. The mean

314 snow depth between first and last snow was $0.55 \mathrm{~m}$. Subsurface thermistors were deployed at 2-

315 and 10-cm depths; when recovered, some were found at greater depths, up to $3 \mathrm{~cm}$ deeper than

316 their deployment depths. They recorded temperatures between 11 July 2014 and 10 June 2015;

317 temperatures were not recorded at the beginning of the winter season. As we did not measure

318 temperatures or snow depth in winter 2013-2014, during which the infilled tunnels we

319 documented in spring 2014 were dug, we take temperatures and snow depth recorded during the

320 2014-2015 winter season (Fig. 8) as a proxy for the 2013-2014 winter season. Subsurface

321 temperatures demonstrate a disparity between meadow regions and the forest-meadow boundary;

322 winter temperatures within the meadow were significantly colder than at the forest-meadow 323 boundary (Fig. 8). 

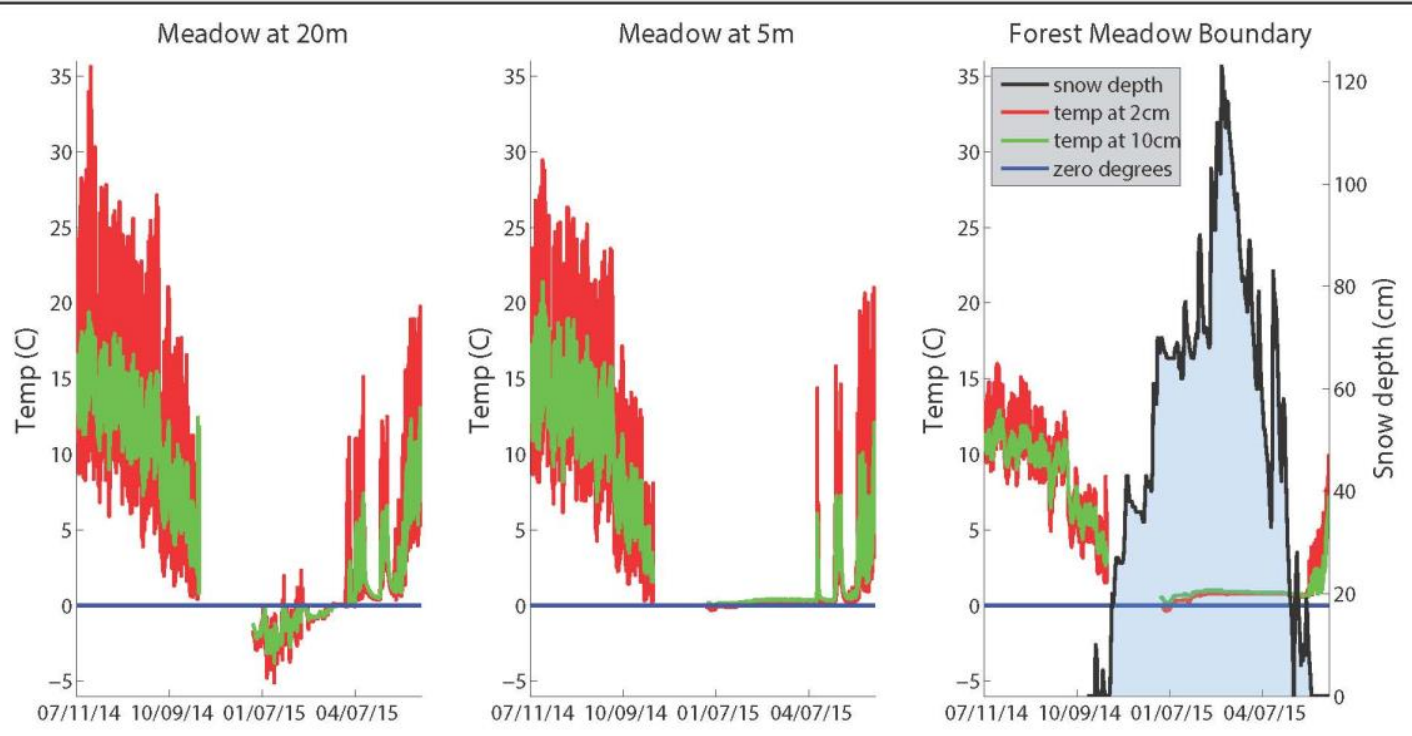

Fig. 8. Temperature time series collected at $2-\mathrm{cm}$ (red time series) and 10-cm (green time series) depths at three locations: $20 \mathrm{~m}$ into the meadow, $5 \mathrm{~m}$ into the meadow, and the forest-meadow boundary. Snow depth measured at the forest-meadow boundary is displayed in black on the right panel. At $20 \mathrm{~m}$ into the meadow (left panel) the temperature is mostly below freezing (blue line $=0^{\circ} \mathrm{C}$ ) and oscillates significantly during the winter, presumably reflecting minimal snow cover. At $5 \mathrm{~m}$ into the meadow from the upslope, upwind meadow edge (middle panel), midwinter temperature is more steady and warmer at $\sim 0^{\circ} \mathrm{C}$; whereas at the meadow edge (right panel), the temperature is yet warmer at $\sim 1^{\circ} \mathrm{C}$ during the period of deep snow cover. Data was not collected in late 2014.

\section{Discussion}

336 Within the subalpine zone of the Colorado Front Range, gophers inhabit meadows but not

337 forests. To explore the long-term geomorphic effect of gophers on the meadow-forest system of 338 the subalpine zone of the Front Range, we utilize this observation along with three primary 339 conclusions from our fieldwork: (i) gopher activities result in the equivalent of $\sim 1 \mathrm{~mm}$ of 
excavated material being deposited across the surface of a meadow each year, (ii) discrete

341 gopher digging patterns can be identified in time and in space at both sites, and (iii) stone lines

342 exist within the meadow region that suggest long-term effects of gopher digging. Here, we

343 explore how gophers have influenced the landscape in the vertical and lateral dimensions.

\section{5.1. Spatial and temporal digging patterns}

345 Despite the ability of the northern pocket gopher to live in a greater set of soil types and range of

346 topography than any other pocket gopher species in Colorado (Miller, 1964), clearly the gophers

347 do not penetrate the forests. Infilled tunnels, which are excavated strictly when snow 348 completely/partially blankets a meadow during the winter, are found primarily at the forest-

349 meadow edge. Mounds, which are generated primarily in August through October, exist strictly

350 within the meadow region and in a 'patchy' pattern. Gophers are relatively solitary (e.g., Miller,

351 1948) and antisocial animals (e.g., Miller, 1957); therefore it is likely that each aggregation of

352 mounds was generated by one gopher. This implies that $\sim 5-7$ gophers inhabited each meadow

353 (Fig. 6), and suggests that gopher densities are 28-39 and 48-67 $\mathrm{ha}^{-1}$ in the upper and lower sites,

354 respectively. These numbers overlap with those acquired in Vaughan's (1969) study within

355 subalpine Colorado parks, where densities of 6.2-12.4 and 14.8-34.6 ha $^{-1}$ were observed in early

356 summer and late summer, respectively.

357 By utilizing the infilled tunnels and mounds as proxies for gopher subsurface location, the data

358 suggests gophers spend the winter months at the forest-meadow edge and then migrate into the

359 meadows (as well as continue to dig near the forest-meadow edges) where they reside until the

360 ensuing winter. We hypothesize that the winter trends are driven primarily by the spatial pattern

361 of snow depth. Snow serves as an insulator and thus governs the thermal state of the near-surface

362 soil. In a study in the alpine landscape on nearby Niwot Ridge, Thorn (1978) found that gopher 
363 density was much higher where snow was thicker (lee side and saddle of the ridge) than on the

364 windswept west-facing hillslope. He later reported (Thorn, 1982) that the spatial variability of

365 gopher activity and associated disturbance is dependent upon winter snowpack. During the

366 winter within the more complex ecosystem of the forested subalpine environment, we observe

367 that the temperature at depth is more steady and warmer at the forest-meadow edge, where snow

368 is deep, and is colder and oscillates significantly toward the center of the meadow, where snow is

369 thin (Fig. 8). Snow is deeper at the forest-meadow edge because of protection from the wind, in

370 contrast with the windswept, thinly snow-mantled meadow center (Figure 9).

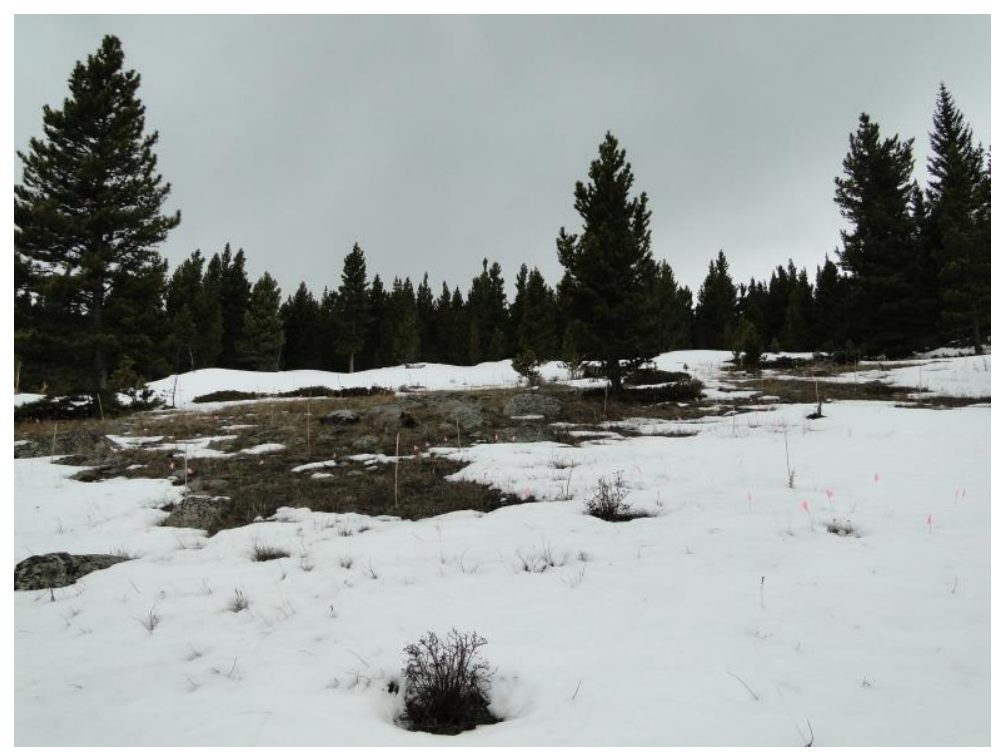

372 Fig. 9. Photograph of the upper site, looking upslope from near the bottom of the study plot.

373 One can observe minimal to zero snow cover in the center of the meadow whereas the snow 374 appears thickest at the most upslope zone along the forest-meadow boundary.

376 Additional drivers of gopher digging patterns could potentially be linked to the onset of breeding 377 season (Miller and Bond, 1960; Cox and Hunt, 1992), the availability of herbaceous food (Cox 
378 and Hunt, 1992), and soil moisture (e.g., Miller, 1948; Verts and Carraway, 1999, and references

379 therein). These links remain to be explored. While gopher tunnel system spacing is roughly

380 uniform at study sites in northern Arizona (Reichman et al., 1982) and likely others inhabited by

381 pocket gophers, such as shortgrass prairies (Grant et al., 1980), alfalfa fields (Miller, 1957), and

382 grassland basins (Black and Montgomery, 1991), this is most likely not the case within our study

383 area in any particular year. Assuming that mounds are a proxy for subsurface tunnel location,

384 clearly the tunnel spacing at our study sites is not uniform on an annual basis (Fig. 6). This may

385 be related to the high concentration and random locations of large boulders in the glacial till in

386 which this landscape is developed. This undoubtedly governs gopher tunneling strategies and

387 vegetation dynamics within the meadows.

389 Here we begin to discuss the details of the lateral and vertical sediment transport driven by 390 gopher excavation activity. In this study, average mound volumes were 4006 and $5842 \mathrm{~cm}^{3}$ for

391 the upper and lower sites, respectively. We note that disparity in reported mound volumes 392 between this study and others (Smallwood and Morrison, 1999, and references therein, report an 393 average mound volume of $0.0158 \mathrm{~m}^{3}$ for T. talpoides) could result from a variety of reasons. One 394 of these, in our case, is that volume measurements are dependent on the interval between surveys 395 and the definition of 'mound'. Expansion of individual mounds was captured by our 396 approximately weekly surveying. In our terminology, each expansion is considered to be a new 397 'mound' because it is a unique and independent 'mound-building event'; if mounds were 398 surveyed less frequently, only the final mound product would be noted and would therefore be 399 larger. Mound volumes can also vary depending on the measurement technique and on weather: 400 wet and windy conditions are more prone to transport sediment from the original mound 
401 position. Thus, instead of comparing average mound volume, we compare the total amount of

402 material that surfaces during the year when investigating the broader geomorphic impact of

403 gophers on the landscape. Therefore it is the 2.32 and $0.82 \mathrm{~m}^{3}$ of material that was excavated to

404 the surface in the form of mounds and infilled tunnels at the upper and lower sites, respectively,

405 on which we focus.

406 The intensity of gopher excavation at our sites is $\sim 2.32 \mathrm{~m}^{3} / 1800 \mathrm{~m}^{2}$ and $0.82 \mathrm{~m}^{3} / 1050 \mathrm{~m}^{2}$ at the

407 upper and lower sites, respectively, or roughly 12.9 and $7.8 \mathrm{~m}^{3} \mathrm{ha}^{-1} \mathrm{y}^{-1}$ for the upper and lower

408 sites, respectively. This falls within but at the low end of the excavation rates reported for some

409 other settings (1.43-832.95 $\left.\mathrm{m}^{3} \mathrm{ha}^{-1} \mathrm{y}^{-1}\right)$ (Smallwood and Morrison, 1999, and references therein).

410 These numbers are more informative than average mound volumes when assessing gopher

411 impact on landscape evolution because they are rates rather than volumes. In the next section,

412 we utilize these values along with stone lines to evaluate the geomorphic signal of gophers.

\section{5.3. Stone lines generated by gopher activity}

414 We had anticipated that the probing data would reveal stone lines in the meadows, as indeed we

415 found. We acknowledge that the method we used cannot distinguish between rocks, roots, or 416 other impenetrable objects. However, in the primarily open meadows (Figs. 4C and 4D), we

417 assume the depth to resistance is generated by cobbles in the subsurface. Test pits were not dug

418 to explore the details of the subsurface -- excavation is not permitted within the study areas

419 because this is an archaeologically sensitive area. To explore what one might expect in a glacial

420 till with randomly distributed cobbles at depth, we model the depth to resistance distribution in a 421 randomly assembled glacial till. We suggest that the model results (Fig. 7) implies that the 422 original random distribution of clasts with depth has been significantly altered and further 423 suggest that this reflects the digging of gophers. Furthermore, the observed depth of maximum 
424 resistance accords with the known preference of gophers to dig in the rooting zone of plants,

425 their food source. If gophers generate the stone lines and gophers are not to be found in present

426 forests, we argue that robust probing resistance data within the forest region, which is able to

427 distinguish between stones and roots, would be very useful in assessing the longevity of forests.

\section{5.4. Stone lines as evidence for vertical sediment transport}

429 Gophers appear to be efficient bioturbators. Here we assess the timescales for turnover of the

430 meadow biomantle. Miller (1957) stated that $80 \%$ of the Sacramento Valley pocket gopher

431 tunnel system is found in the upper $31 \mathrm{~cm}$ of the soil, with $40 \%$ existing between 15 and $21 \mathrm{~cm}$.

432 Reichman and Seabloom (2002) stated that pocket gophers primarily dig between 6 and $20 \mathrm{~cm}$

433 depth. Our data on depth to significant resistance (= stones) peaks at $\sim 15 \mathrm{~cm}$ within the

434 meadows. This echoes the data of this prior research, suggesting that we may interpret the

435 resistance measurements (Fig. 7) as a stone line generated by gopher digging habits (Johnson,

436 1989). From the total material excavated to the surface and area of each meadow, we calculate

437 an aerial average of 1.3 and $0.8 \mathrm{~mm}$ of excavated material spread over the upper and lower sites,

438 respectively $\left[=\left(2.32 \mathrm{~m}^{3} / 1800 \mathrm{~m}^{2}\right)\right.$ and $\left.\left(0.82 \mathrm{~m}^{3} / 1050 \mathrm{~m}^{2}\right)\right]$. Utilizing these values and the stone

439 line depth of $15 \mathrm{~cm}$, we infer that the top $15 \mathrm{~cm}$ of the study meadows will completely turn over

440 approximately once every couple centuries $[=[150 \mathrm{~mm} /(1.3 \mathrm{~mm} / \mathrm{y})]$ to $[150 \mathrm{~mm} /(0.8 \mathrm{~mm} / \mathrm{y})]$

441 years]. Apparently, the mixing of the near subsurface of a meadow is therefore expected to be

442 accomplished relatively quickly by gopher activity. These timescales are roughly comparable to

443 the decadal-century timescales required for areal resurfacing of the meadows: 49.4 and 95.4

444 years for the upper and lower sites, respectively. 
446 Gabet (2000) noted that material mobilized by gophers can be broken into two horizontal

447 distances and argued that volumetric sediment transport rate, $q_{s}\left[\mathrm{~L}^{3} / \mathrm{LT}\right]$, resulting from gopher 448 excavation may be evaluated using

$$
q_{s}=M P R * V *\left(a^{\prime}+b^{\prime}\right)
$$

450 where $M P R$ is the mound production rate [number of mounds $\mathrm{L}^{-2} \mathrm{~T}^{-1}$ ], $V$ is average mound 451 volume $\left[\mathrm{L}^{3} /\right.$ mound], and the distances $a^{\prime}$ and $b^{\prime}$ are related to distances $a$ and $b$ measured 452 parallel to the hillslope:

$$
\begin{gathered}
a^{\prime}=a \cos (\alpha) \cos (S) \\
b^{\prime}=b \cos (S)
\end{gathered}
$$

453 where $a$ is the hillslope parallel distance between the centroid of the tunnel and tunnel opening, $b$ 454 is the hillslope parallel distance between the tunnel opening and mound centroid (Fig. 1B), $S$ is 455 the slope of the hill, and $\alpha$ is the angle between the tunnel and the line of steepest descent (the 456 fall line). The subsurface transport distance, $a$, was not surveyed in this study but is calculated 457 by back-calculating the tunnel distance required to produce the observed mound/infilled tunnel 458 volume (we assume a tunnel radius of $3 \mathrm{~cm}$ ). We incorporate infilled tunnel data into all 459 appropriate calculations, given that they represent a significant amount of material excavated and 460 relocated to the surface; they are considered and quantitatively examined here in the same 461 fashion as mounds. We assume that $\alpha$ is 0 and thus assume that all tunnels are constructed 462 directly downslope; this yields a maximum downslope transport estimate. We also assume that 463 for all mounds/infilled tunnels the surface component of motion $b=0.05 \mathrm{~m}$. Table 1 displays the 464 values that we use. 
Table 1 Values utilized to perform Gabet (2000) sediment transport calculations

\begin{tabular}{|c|c|c|c|}
\hline Parameter & Upper site value & Lower site value & Note \\
\hline MPR & 0.32 mounds $* \mathrm{~m}^{-2} * \mathrm{y}^{-1}$ & 0.16 mounds $* \mathrm{~m}^{-2} * \mathrm{y}^{-1}$ & Includes infilled tunnels and mounds \\
\hline V & $0.004 \mathrm{~m}^{3}$ & $0.005 \mathrm{~m}^{3}$ & Includes infilled tunnels and mounds \\
\hline $\mathrm{a}$ & $1.41 \mathrm{~m}$ & $1.75 \mathrm{~m}$ & $\begin{array}{l}\text { Back-calculated utilizing } \mathrm{V} \text { and assumed } \\
\text { tunnel radius }=3 \mathrm{~cm}\end{array}$ \\
\hline b & $0.05 \mathrm{~m}$ & $0.05 \mathrm{~m}$ & Estimated \\
\hline$\alpha$ & 0 & 0 & $\begin{array}{l}\text { Assumption that tunnels are constructed } \\
\text { downslope and parallel to line of steepest } \\
\text { decent }\end{array}$ \\
\hline S tangent(slope) & 0.23 & 0.17 & Acquired from LiDAR \\
\hline a' & $1.37 \mathrm{~m}$ & $1.73 \mathrm{~m}$ & Equation 2 \\
\hline b' & $0.05 \mathrm{~m}$ & $0.05 \mathrm{~m}$ & Equation 2 \\
\hline
\end{tabular}

466 We utilize Eq. (1) and values in Table 1 to calculate volumetric transport rates of 0.002 and

$4670.001 \mathrm{~m}^{3} \mathrm{~m}^{-1} \mathrm{y}^{-1}$ for the upper and lower sites, respectively. This can be transformed to a

468 sediment mass discharge rate [M/L/T] utilizing Eq. (3):

$$
Q=\rho_{r} q_{s}
$$

470 where $\rho_{r}$ is the density of regolith and is assumed to be $1500 \mathrm{~kg} / \mathrm{m}^{3}$. Equation (3) yields mass 471 discharge rates of 2.75 and $2.08 \mathrm{~kg}^{1} \mathrm{~m}^{-1} \mathrm{y}^{-1}$ for the upper and lower sites, respectively. If we 472 assume a common hillslope geomorphic transport law of the form $Q=-k S$, where $S$ is the 473 tangent of the slope, we may estimate the hillslope transport efficiency, $k$, and landscape 474 diffusivity, $\kappa$, as

$$
\begin{gathered}
k=\frac{Q}{S} \\
\mathrm{~K}=\frac{k}{\rho_{r}}
\end{gathered}
$$

475 The resulting transport efficiencies, $k$, are 11.7 and $12.2 \mathrm{~kg}^{1} \mathrm{~m}^{-1} \mathrm{y}^{-1}$ for the upper and lower sites, 476 respectively; and the diffusivity, $\kappa$, is $0.008 \mathrm{~m}^{2} \mathrm{y}^{-1}$ for both the upper and lower sites. 
477 Full accounting of the geomorphic roles of gophers in the evolution of a given landscape requires

478 field documentation of surface and subsurface transport distances. At our sites, displacements of 479 surficial material (Fig. 1B) can be attributed to diffusive processes (e.g., Anderson and 480 Anderson, 2010) such as frost heave, rainsplash, and biological agents, including ungulates (Fig.

481 10). Ungulates leave large, deeply embedded footprints on the surface that presumably collapse 482 tunnels and disturb mounds in the vertical and downslope directions (Fig. 10). Furthermore, 483 frequent matted patches of grasses are observed suggesting that ungulates frequently rest or sleep 484 within the meadows. When the mounds initially erupt, their densities are lower than that of 485 undisturbed ground (Butler and Butler, 2009). Thus, the evolution of mounds should include any 486 motion during the redensification of the material. We observe that mounds evolve to become 487 flatter as they age, and we hypothesize that this occurs from rainsplash and other processes that 488 promote settling. We hypothesize that rainsplash that occurs during the early life of a mound, 489 when they are relatively bald of vegetation and therefore lack cohesion associated with roots, 490 also promotes preferential downslope motion of the fine grains (Gabet and Dunne, 2003, 2004; 491 Furbish et al., 2007,2009). This should result in a flattening or deflation of the mound and should 492 coarsen its surface.

493 Butler and Butler (2009) have hypothesized that tree seedling establishment may be promoted by 494 the presence of mounds with their reduced soil density. We have witnessed the rapid 495 colonization/recovery of grasses and forbs on the mounds. Recovery of plant cover should 496 increase the cohesion associated with each species' root structure and provide a canopy that 497 serves as an umbrella to damp the direct effects of rain and wind. As the duration of exposure to 498 these vegetation elements will limit the degree to which mound material may be moved 
499 downslope, we encourage a future study linking vegetation dynamics to gopher-driven sediment

500 transport.

501

502
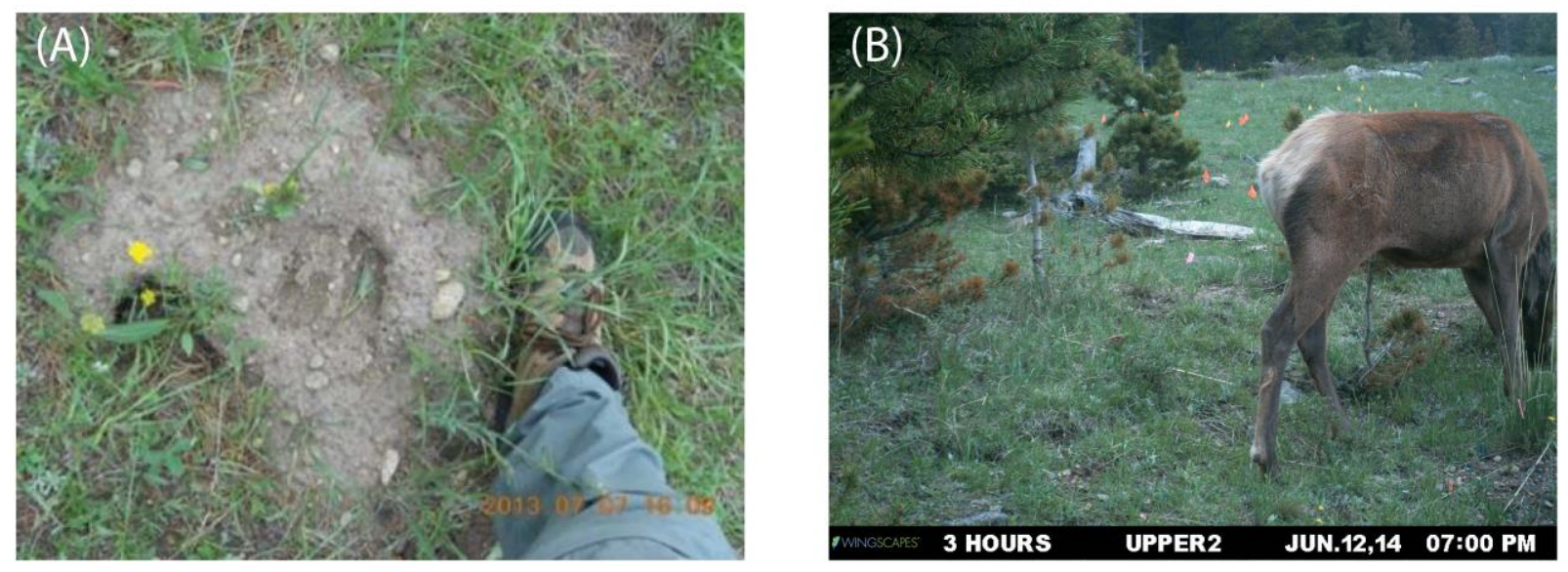

503 Fig. 10. Ungulates are subaerial biogeomorphic agents. (A) A hoof print embedded in a gopher

504 mound is a common sight. (B) A time-lapse image captures a deer grazing at dusk at the upper

505 site; note pin flags in the distance denoting mound locations.

\subsection{Landscape-scale lateral transport processes}

507 We hypothesize that the forest-meadow subalpine landscape of the Front Range is more broadly

508 impacted by gopher-generated geomorphic work in the long term. This scenario requires that the

509 meadow-forest boundaries be relatively mobile and in particular that areas now dominated with

510 forests were once meadows. We propose that this can occur in three ways: (i) long-term climate-

511 driven changes in forest versus meadow cover, including the increase in tree cover after

512 glaciation; (ii) invasion of gophers into areas cleared of tree cover by natural forest fires; and (iii)

513 anthropogenic-driven declines in tree cover due to cutting and to deliberate and accidental fires. 
514 First, estimates of forest expansion to higher elevations over the last $10.6 \mathrm{ka}$ within the Medicine

515 Bow Mountains in nearby Wyoming (e.g., Minckley et al., 2012) suggested that in the past many

516 areas that are mostly forested now (including the surroundings of our study sites) were solely or

517 predominantly meadows. Because northern pocket gophers are abundant in alpine and subalpine

518 habitats, this would have allowed far larger extent of their effects in the past. The forest-meadow

519 systems within the subalpine of the Front Range will have moved about sufficiently since

520 moraines were formed $\sim 18 \mathrm{ka}$ that the landscape has been repeatedly subjected to the efficient

521 alterations of the surface by hot-spots of gopher activity in the meadows.

522 Second, forest fires wipe the landscape clean of tree cover, allowing gophers to reestablish in

523 these now unforested areas. A patchy meadow-forest complex will likely evolve as the

524 landscapes recover. This may involve self-organization of the forest-meadow complex in part by

525 competition between tree encroachment and gopher herbivory. Sibold et al. (2006) documented

526 that a roughly 30,000-ha region of subalpine forest within the nearby Rocky Mountain National

527 Park has experienced 22 stand-replacing fires between 1654 and 2002; fires occur within this

528 landscape on approximately decadal timescales. It is therefore plausible that our study sites

529 have experienced a similar fire history, given the fire history of the montane and subalpine zones

530 of the Front Range (Veblen and Lorenz, 1991), and thus that forest fires have repeatedly reset the

531 position of the forest-meadow boundaries at our sites. Charred tree stumps and surface wood in

532 nearby meadows suggest that fire has indeed recently affected the landscape. This would imply

533 that the meadow-forest system has repeatedly reestablished itself, likely in different places over

534 time, effectively randomizing the effects of gophers on the landscape. This suggests a possible

535 mechanism by which the geomorphic impacts of gophers have migrated through the entire 536 landscape. 
537 Finally, within the montane and subalpine zones of the Front Range, forests have significantly

538 reorganized over the last 150 years in response to anthropogenic activities that include logging,

539 mining, town construction, and railroad construction (Veblen and Lorenz, 1991). The decades to

540 century-scale forest migration back into cleared lands in the aftermath of these disturbances

541 suggests that gophers have had the opportunity to impact much of the Front Range landscape.

542 While feedbacks between gophers and the forest edge through herbivory of seedlings is not

543 required for the gophers to have had a significant impact on the landscape, we have initiated a

544 numerical modeling effort to explore the nature of the meadow-forest pattern evolution that

545 depends upon the relationship between tree age, tree density, and gopher density. By exploring

546 the possibility that gophers mediate the evolution of the forest-meadow boundary, we will probe

547 the full richness of this 'forest-meadow-gopher' system.

\section{6. Conclusions}

549 Within the subalpine zone of the Colorado Front Range, meadows dot the forested landscape.

550 Within this till-mantled landscape, the Northern Pocket Gopher clearly is the dominant 551 geomorphic worker within the meadows and is not a player in the forests. At the meadow scale 552 on an annual timescale, spatial and temporal patterns of gopher-generated surface mounds and 553 infilled tunnels reveal that the transport of sediment by gophers is neither steady nor uniform. 554 The seasonal pattern likely reflects subsurface temperatures that are, in turn, governed by 555 patterns of snow depth. Field documentation during 2014 suggests that gophers play a 556 significant role in vertically churning the $\sim 15$-cm-thick biomantle of the meadow on 557 approximately century timescales. We capture the efficiency of lateral gopher sediment 558 transport with a landscape diffusivity, $\kappa$, of $0.008 \mathrm{~m}^{2} \mathrm{y}^{-1}$. Forest-meadow boundaries are not 559 stationary; meadow-forest complexes repeatedly self-organize in the aftermath of fires and other 
560 natural and anthropogenic disturbances. Over millennial timescales, the migration of meadows

561 will inevitably spread the influence of gophers in vertically churning the biomantle and in

562 transporting sediment downslope in this landscape.

\section{Acknowledgements}

564 We are very thankful to Emmanuel J. Gabet, Richard A. Marston, and one anonymous reviewer

565 for very insightful and constructive reviews of the manuscript. This material is based upon work

566 supported by the National Science Foundation under Grant Nos. EAR-1239281 and EAR-

5671331828 (the Boulder Creek Critical Zone Observatory). We are beyond thankful for field work

568 assistance from: Jorgie Marquez, Taylor Winchell, Clark Winchell, Melissa Foster, William

569 Armstrong, Amanda Brenner, David Schellhase, Andrea Webber, Timothy Salazar, Harrison

570 Gray, Ethan Welty, Kristina Cowell, Dillon Ragar, Jamie Glass, Jered Karr, Teal Potter, John

571 McFadden Jr., Simon Pendleton, Clayton Jensen, Brett Heitshusen, Rachel Glade, Alex Eddy,

572 Satya Akquia, and Ryan Serrano.

\section{References}

574 Andersen, D.C., 1978. Observations on reproduction, growth, and behavior of the northern

575 pocket gopher (Thomomys talpoides). Journal of Mammalogy 59(2), 418-422.

576 Anderson, R.S., Anderson, S.P., 2010. Geomorphology: The Mechanics and Chemistry of $577 \quad$ Landscapes. Cambridge University Press, 637 p.

578 Anderson, S.P., Anderson, R.S., Tucker, G.E., 2012. Landscape scale linkages in critical zone 579 evolution. Comptes Rendus Geoscience 344(11), 586-596.

580 Anderson, S.P., Anderson, R.S., Tucker, G.E., Dethier, D.P., 2013. Critical zone evolution: 581 Climate and exhumation in the Colorado Front Range, in Abbott, L.D., and Hancock, G.S., 582 eds., Classic Concepts and New Directions: Exploring 125 Years of GSA Discoveries in 
the Rocky Mountain Region. Geological Society of America Field Guide 33, 1-18, doi:10.1130/2013.0033(01).

Armstrong, D.M., Fitzgerald, J. P., Meaney, C.A., 2011. Mammals of Colorado, Second Edition. University Press of Colorado, 620 p.

Black, T.A., Montgomery, D.R., 1991. Sediment transport by burrowing mammals, Marin County, California. Earth Surface Processes and Landforms 16(2), 163-172.

Butler, D.R., 1995. Zoogeomorphology: Animals as Geomorphic Agents. Cambridge University Press, $231 \mathrm{p}$.

Butler, D.R., Butler, W.D., 2009. The geomorphic effects of gophers on soil characteristics and sediment compaction: a case study from alpine treeline, Sangre de Cristo Mountains, Colorado, USA. The Open Geology Journal 3, 82-89.

594 Chamberlain, K., 2002. Performance testing of the Trimble GeoXT global positioning system receiver. Draft report - global positioning system. U.S. Department of Agriculture Forest Service, October 2002, http://www.fs.fed.us/database/gps/ mtdc/geo_xt/trimble_geoxt.pdf

599 Cox, G.W., Hunt, J., 1992. Relation of seasonal activity patterns of valley pocket gophers to 600 temperature, rainfall, and food availability. Journal of Mammalogy 73(1), 123-134.

601 Criddle, S., 1930. The prairie pocket gopher, Thomomys talpoides rufescens. Journal of 602 Mammalogy 11(3), 265-280.

603 Darwin, C., 1881. The Formation of Vegetable Mould: Through the Action of Worms, with 604 Observations on Their Habits. With illustrations. John Murray. 
605 Ellison, L., 1946. The pocket gopher in relation to soil erosion on mountain 606 range. Ecology 27(2), 101-114.

607 Furbish, D.J., Hamner, K.K., Schmeeckle, M., Borosund, M.N., Mudd, S.M., 2007. Rain splash

608 of dry sand revealed by high-speed imaging and sticky paper splash targets. Journal of 609 Geophysical Research: Earth Surface 112(F1), doi:10.1029/2006JF000498.

610 Furbish, D.J., Childs, E.M., Haff, P.K., Schmeeckle, M.W., 2009. Rain splash of soil grains as a 611 stochastic advection-dispersion process, with implications for desert plant-soil interactions 612 and land-surface evolution. Journal of Geophysical Research: Earth Surface 114(F3), doi:10.1029/2009JF001265

614 Gabet, E.J., 2000. Gopher bioturbation: Field evidence for non-linear hillslope diffusion. Earth 615 Surface Processes and Landforms 25(13), 1419-1428.

616 Gabet, E.J., Dunne, T., 2003. Sediment detachment by rain power. Water Resources 617 Research 39(1), ESG 1-1-ESG 1-12

618 Gabet, E.J., Dunne, T., 2004. Correction to "Sediment detachment by rain power". Water 619 Resources Research 40(8) W08901, DOI:10.1029/2004WR003422.

620 Gabet, E.J., Reichman, O.J., Seabloom, E.W., 2003. The effects of bioturbation on soil processes 621 and sediment transport. Annual Review of Earth and Planetary Sciences 31(1), 249-273.

622 Gabet, E.J., Perron, J.T., Johnson, D.L., 2014. Biotic origin for Mima mounds supported by 623 numerical modeling. Geomorphology 206, 58-66.

624 Gilbert, G.K., 1909. The convexity of hilltops. The Journal of Geology 17(4), 344-350.

625 Grant, W.E., French, N.R., Folse Jr., L.J., 1980. Effects of pocket gopher mounds on plant 626 production in shortgrass prairie ecosystems. The Southwestern Naturalist 25(2), 215-224. 
627 Grinnell, J., 1923. The burrowing rodents of California as agents in soil formation. Journal of 628 Mammalogy 4(3), 137-149.

629 Inouye, R.S., Huntly, N., Wasley, G.A., 1997. Effects of pocket gophers (Geomys bursarius) on 630 microtopographic variation. Journal of Mammalogy 78(4), 1144-1148.

631 Johnson, D.L., 1989. Subsurface stone lines, stone zones, artifact-manuport layers, and 632 biomantles produced by bioturbation via pocket gophers (Thomomys bottae). American 633 Antiquity 54(2), 370-389.

634 Knight, J., 2009. Infilled pocket gopher tunnels: seasonal features of high alpine plateaux. Earth $635 \quad$ Surface Processes and Landforms 34(4), 590-595.

636 Madole, R.F., Van Sistine, D.P., Michael, J.A., 1998. Pleistocene glaciation in the upper Platte 637 River drainage basin, Colorado: U.S. Geological Survey Scientific Investigations Map $638 \quad 2644$, scale 1:500,000.

639 Miller, M.A., 1948. Seasonal trends in burrowing of pocket gophers (Thomomys). Journal of $640 \quad$ Mammalogy 29(1), 38-44.

641 Miller, M.A., 1957. Burrows of the Sacramento Valley pocket gopher in flood-irrigated alfalfa 642 fields. Hilgardia 26(8), 431-452.

643 Miller, R.S., 1964. Ecology and distribution of pocket gophers (Geomyidae) in Colorado. $644 \quad$ Ecology 45(2), 256-272.

645 Miller, R.S., Bond, H.E., 1960. The summer burrowing activity of pocket gophers. Journal of 646 Mammalogy 41(4), 469-475.

647 Minckley, T. A., Shriver, R. K., Shuman, B., 2012. Resilience and regime change in a southern 648 Rocky Mountain ecosystem during the past 17000 years. Ecological Monographs 82(1), $649 \quad 49-68$. 
650 Reichman, O.J., Seabloom, E.W., 2002. The role of pocket gophers as subterranean ecosystem 651 engineers. Trends in Ecology and Evolution 17(1), 44-49.

652 Reichman, O.J., Whitham, T.G., Ruffner, G.A., 1982. Adaptive geometry of burrow spacing in 653 two pocket gopher populations. Ecology 63(3), 687-695.

654 Seabloom, E.W., Reichman, O.J., Gabet, E.J., 2000. The effect of hillslope angle on pocket 655 gopher (Thomomys bottae) burrow geometry. Oecologia 125(1), 26-34.

656 Sibold, J.S., Veblen, T.T., González, M.E., 2006. Spatial and temporal variation in historic fire 657 regimes in subalpine forests across the Colorado Front Range in Rocky Mountain National 658 Park, Colorado, USA. Journal of Biogeography 33(4), 631-647.

659 Smallwood, K.S., Morrison, M.L., 1999. Estimating burrow volume and excavation rate of 660 pocket gophers (Geomyidae). The Southwestern Naturalist 44(2), 173-183.

661 Thorn, C.E., 1978. A preliminary assessment of the geomorphic role of pocket gophers in the 662 alpine zone of the Colorado Front Range. Geografiska Annaler. Series A. Physical 663 Geography 60(3/4), 181-187.

664 Thorn, C.E., 1982. Gopher disturbance: its variability by Braun-Blanquet vegetation units in the 665 Niwot Ridge alpine tundra zone, Colorado Front Range, USA. Arctic and Alpine Research 666

667 Trimble. 2005. Trimble GeoExplorer II specifications, 668 http:// trl.trimble.com/docushare/dsweb/Get/Document-10404/geo2_specs.pdf

669 Vaughan, T. A., 1969. Reproduction and population densities in a montane small mammal 670 fauna. Miscellaneous Publications, Museum of Natural History, University of Kansas, 51, $671 \quad 51-74$. 
672 Veblen, T.T., Lorenz, D.C., 1991. The Colorado Front Range: a Century of Ecological Change.

673 Univ of Utah Pr, 186 p.

674 Verts, B. J., Carraway, L.N., 1999. Thomomys talpoides. Mammalian Species, No. 618, 1-11.

675 Vleck, D., 1979. The energy cost of burrowing by the pocket gopher Thomomys bottae. $676 \quad$ Physiological Zoology 52(2), 122-136.

677 Vleck, D., 1981. Burrow structure and foraging costs in the fossorial rodent, Thomomys bottae. $678 \quad$ Oecologia 49(3), 391-396.

679 Warren, E.R., 1937. Notes on pocket gophers. Journal of Mammalogy 18(4), 473-477.

680 Yoo, K., Amundson, R., Heimsath, A.M., Dietrich, W.E., 2005. Process-based model linking

681 pocket gopher (Thomomys bottae) activity to sediment transport and soil thickness.

682 Geology 33(11), 917-920.

683 Zaitlin, B., Hayashi, M., 2012. Interactions between soil biota and the effects on

684 geomorphological features. Geomorphology 157, 142-152. 